Paweł Kaleta

ORCID: https://orcid.org/0000-0001-6159-0997

The John Paul II Catholic University of Lublin, Poland

\title{
Perspectives \\ on the Development of Sponsorship of Catholic Ministerial Organizations with Particular Reference to Health Care*
}

\begin{abstract}
Sponsorship in this paper is the formal relationship between an authorized Catholic organization and a recognized apostolic $\mathrm{u}$
\end{abstract}

* This scientific work is the realization of scientific project registration number: UMO2017/25/B/HS5/00739 financed by the National Science Centre, Poland. 
ndertaking to promote and sustain Christ's ministry to people in need. Sponsorship is not a static reality. Radical changes which have occurred in charitable works, largely due to the decline in religious vocations and the aging of members of institutes, led sponsoring leaders to seek for and find new approaches to sponsorship whereby their ministry could continue without compromising their identity. The purpose of this article is to draw attention to certain perspectives of the evolving understanding of sponsorship which is regularly in the process of being transformed and reshaped. It faces many challenges regarding the continuing Catholic identity of the sponsored works and the recognition of numerous new opportunities for future forms of sponsorship. This study explores certain canonical and practical perspectives for the development of the sponsorship of various forms of Catholic ministerial organizations, with particular reference to health care.

\section{Keywords}

Sponsorship, charity organizations, Catholic healthcare service, educational institutions, social service

\section{Introduction}

Sponsorship, as it is used today in reference to various apostolic works carried out by the Church in the areas of healthcare, education, and social services, is not a term we find used in canon law. The law dictionary defines a sponsor as "surety; one who makes a promise or gives security for another". In canon law it usually refers to the relationship which a juridic person (traditionally the religious congregation or diocese) maintains with an apostolate in order for it to be able to exercise its activities on behalf of the Church and in its name. ${ }^{2}$

${ }^{1}$ H.C. Black, Black's Law Dictionary: Definitions of the Terms and Phrases of American and English Jurisprudence Ancient and Modern, St. Paul 1990, West Publishing Co., p. 1402. Sponsors act not only in the name of a particular health institution or service but also on behalf of the faith community that bears witness to Jesus' call for love and healing. Catholic Health Association of the United States, Core Competencies of Sponsor, Missouri 2017, St. Louis, p. 1.

${ }^{2}$ J.K. Murphy, The governance of Church institutions and protection of Catholic identity with particular reference to Ontario, Canada, Roma 1995, Pontificia Università Lateranense, p. 145. Sponsorship is a reservation of canonical control by the juridic person that founded and/or sustains an apostolate that remains canonically a part of the Church entity. This retention of control need not be such as to create civil law liability on the part of the sponsor for 
Today, sponsorship is generally accepted to be a formal relationship between an authorized Catholic organization and a recognized apostolic undertaking, e.g. hospital, university, clinic, nursing home or other institution; it is entered into for the sake of promoting and sustaining Christ's ministry to people in need. ${ }^{3} \mathrm{Ca}$ nonical literature points to the baptismal liturgy in which the godparent makes the baptismal promises as the sponsor of the infant being baptized. ${ }^{4}$ In addition to maintaining existing relationships, sponsors are often called upon to ensure a smooth transition to new forms of relationships when required. ${ }^{5}$

For this reason, sponsorship is not a static reality. ${ }^{6}$ Radical changes which have occurred in clinical practice and in educational techniques due to technological advances, increased globalization, changes in the Church affecting the ecclesial mission, changing times and greater collaboration with lay people, have led the leaders of Catholic apostolic activities to search for new sponsorship models. ${ }^{7}$ Using Catholic health care as an example, we can say that it is constantly in the process of being transformed and reshaped. ${ }^{8}$ Over a quarter century ago, in 1993, the United States Conference of Catholic Bishops drew up criteria for

corporate acts or omissions but should be enough for the canonical stewards of the sponsoring organization to meet their canonical obligations of faith and administration regarding the activities of the incorporated apostolate. See J. Hite, A Primer on Public and Private Juridic Persons: Applications to the Catholic Health Care Ministry, St. Louis 2000, Catholic Health Association of the United States, p. 37.

${ }^{3}$ Catholic Health Association of the United States provides numerous programs, services and resources to help sponsors of Catholic health care live out and understand their roles better. For more information about Catholic Health Association of the United States see: www. chausa.org

${ }^{4}$ A.J. Maida, N.P. Cafardi, Church Property, Church Finances, and Church-related Corporations: A Canon Law Handbook, St. Louis 1984, Catholic Health Association of the United States, p. 213. D.C. Conlin pointed out that the term "sponsor" does not transfer well by analogy to Book V of the 1983 Code of Canon Law, which covers the temporal goods of the Church. To accept sponsorship responsibility for a person entering the Catholic faith is not the same reality as to claim ownership or sponsorship of a Catholic health care facility, Sponsorship at the Crossroads, "Health Progress" 82 (2001) 4, p. 20.

5 F.G. Morrisey, Toward Juridic Personality, "Health Progress" 82 (2001) 4, p. 27.

6 Depending on the context, the terms "institution" and "services" encompass the variety of settings in which Catholic ministry is provided.

7 Association of Catholic Colleges and Universities, Points of Distinction: The Catholic College and University President, Washington 2018, Association of Catholic Colleges and Universities, p. 1.

${ }^{8}$ Given the extremely active nature of the debate about healthcare reform in the United States, any overview runs the risk of obsolescence from the moment of its formulation. Many 
evaluating the healthcare reform. These criteria included: respect for life; priority concern for the poor; universal access; comprehensive benefits; pluralism; quality; cost containment and controls; and equitable financing. ${ }^{9}$ They are still applicable today, although in a different context in some places. More recently, on June 22, 2018, the same Conference released a revised version of its Ethical and Religious Directives for Catholic Health Care Services. ${ }^{10}$ This new edition offers well-thought-out guidelines for the Church's vision of health care ministry.

The purpose of this article is to draw attention to certain perspectives of the evolving understanding of sponsorship and its relationship to governance in Catholic institutions and services, in line with the directives of the bishops. This study is addressed primarily to canonists and leaders of sponsorship organizations. The various recommendations are based on new legal arrangements currently being developed in the U.S.A., Australia, Ireland, and Canada, among other places. While, again, our general focus is on healthcare, with appropriate adaptations, the same principles can apply to Catholic social services undertakings, as well as to educational institutions. ${ }^{11}$

\section{Evolution of sponsorship models}

In order to understand better where we are today, it might be helpful to review briefly the evolution of sponsorship structures over the past fifty years.

In the past, the most common form of sponsorship derived from direct ownership of the property and the active presence of many persons identified with the sponsor (for instance, religious on staff) in the daily operation of the institution (e.g. hospital or a school). In addition, the name of the sponsoring congregation was often found in the name of the institution. In a sense, the

years ago, Keane provided a comprehensive review of the topic: P. S. Keane, Health Care Reform: A Catholic View, New York 1993, Paulist Press.

9 United States Conference of Catholic Bishops, Resolution on Health Care Reform, “Origins” 23 (1993-1994) p. 100.

10 The document is available online at www.usccb.org

${ }^{11}$ For a study on sponsorship of Catholic educational institutions, see M. P. Seurkamp, Navigating the Waters of Sponsorship, Washington 2018, Association of Catholic Colleges and Universities. 
work operated as though it were a family business. ${ }^{12}$ However, following the Second Vatican Council, the Catholic Church, moving away from an almost exclusive reliance on religious vocations, began to emphasize the dignity of the baptismal vocation. This renewed emphasis coincided with significant changes in religious institutes, especially with the declining number of religious men and women. This resulted in the increased involvement of lay people undertaking leadership and decision-making positions in Catholic ministry. At the beginning of this stage, however, lay involvement was largely confined to membership on advisory boards.

Over time, sponsorship became more identified with the policy setting of the congregation's board of directors than with the actual delivery of health care services. At the same time, the various ministerial organizations began to acquire "civil recognition" distinct from that of their sponsoring congregations, with standing as civil legal entities. ${ }^{13}$ Their governance was accomplished through an independent board of trustees or directors. ${ }^{14}$ This led to the creation of distinct boards for the various organizations, the membership of which sometimes coincided with the membership of the sponsoring congregations, and, at other times, was totally distinct. ${ }^{15}$

Later, sponsors began to distinguish between the members (i.e., the Congregational leadership) and the board of directors (lay persons and religious). Relations between the members and the board were governed by the use of "reserved powers" which helped maintain the Catholic influence in the works performed by the sponsored entity. ${ }^{16}$ This meant that certain decisions were reserved to the ecclesiastical authority (religious or diocesan) for confirmation before the board could put the decision into effect. This was to ensure an effec-

12 F. G. Morrisey, Our Sponsors Yesterday, Today and Tomorrow, "Health Progress" 94 (2013) 4, p. 57.

${ }^{13}$ The evolution of sponsorship is reflected among others: R. Kealy, Canonical Aspects of Catholic Identity in the Institutional Setting, "Canon Law Society of America Proceedings" 61 (1999) pp. 195-209.

${ }_{14}$ P.M. Dugan, The Sponsorship Relationship: Incorporation and Dissolution Civil and Canon Law Perspectives, in R. Smith, W. Brown, N. Reynolds (eds.), Sponsorship in the United States Context. Theory and Praxis, Alexandria 2006, Canon Law Society of America, p. 76.

15 F.G. Morrisey, Toward Juridic Personality, "Health Progress" 82 (2001) 4, p. 28.

${ }^{16}$ A well-known work by Cardinal Adam Maida and Nicholas Cafardi addressed the issue in detail; see A.J. Maida, N.P. Cafardi, Church Property, Church Finances, and Church-related Corporations: A Canon Law Handbook, St. Louis 1984, Catholic Health Association of the United States, pp. 155-163. 
tive method of protecting the mission as well as the Church's assets. At times, it also made it possible for the separately incorporated work to be eligible for certain grants offered by public sources. With respect to the administration of ecclesiastical goods, canon law reserves certain decisions to the competent ecclesiastical authority. For this reason, certain decisions of incorporated apostolates are reserved to such persons. ${ }^{17}$

With time however, the number of essential reserved powers diminished as sponsors became more comfortable with the idea of having others directly involved in their ministry. ${ }^{18}$ The reserved powers were reduced to essential ones which were focused in three areas: 1) documents (corporate documents, bylaws, mission statements); 2) persons (board members, leadership); and 3) property (sales of land and buildings, bond issues, mortgages, loans).

Some religious institutes then organized their apostolic works into "systems" or "networks", thus freeing the congregational leadership from a number of board meetings relating to each individual institution. For instance, when a congregation operated a number of universities or colleges, or healthcare ministry, ${ }^{19}$ the system coordinated activities relating to ministry. This enabled related institutions to have a basic common vision.

A further step occurred when certain dioceses wished to be partners of various activities formerly carried out by religious. In particular, such partnerships centered around social services offered by the Church (subsidized housing, charitable assistance, etc.). This called for the delicate crafting of the governing documents because both parties were to be considered as equal partners. As a consequence, once institutes and dioceses amalgamated to operate institutions and works jointly, it became appropriate to establish new distinct Church corporations - known as juridic persons (see can. 114) - to assume sponsorship of the joint works. Because such systems often overlapped diocesan limits, it eventually became necessary to have a higher authority grant canonical recognition: thus, the involvement of the Holy See in granting new types of recognition, commonly known as public juridic persons (PJPs).

17 J.K. Murphy, The governance of Church institutions and protection of Catholic identity with particular reference to Ontario, Canada, Roma 1995, Pontificia Università Lateranense, p. 205.

${ }^{18}$ Ministry consists in continuing the mission of the Church in the name of the faith community.

19 In Catholic circles, we say that healthcare is a ministry. In secular terms, we say healthcare is a service. 
At the same time as these developments were taking place, other factors began to make themselves felt. For instance, partnerships were no longer exclusively with Catholic providers. Sometimes they were with other faith-based providers and, sometimes, with community organizations that had no particular background of religious traditions. Under these arrangements, at times, the Catholic sponsors were but a small factor in a large system; at other times, they were the dominant partner. This resulted in a further refinement of reserved powers, some of which were now located at the system level (where a system had been established), rather than in the congregation's general leadership.

The involvement of other-than-Catholic parties in sponsorship of healthcare institutions often led to moral questions, largely due to their offering procedures contrary to Catholic moral teaching, such as therapeutic abortion, euthanasia, ${ }^{20}$ assisted suicide, and direct sterilization. ${ }^{21}$ Catholic institutions could not accept these medical procedures from the perspective of their Catholic identity. These non-negotiable characteristics of Catholic identity had to be precisely enunciated in the legal documents of health care institutions. This was to safeguard the maintenance of Catholic identity and influence the delivery of services for which the ministry was established. This constituted clear information about the Church's position in relation to the protection of human life from conception to natural death. Lengthy discussions took place in regard to what could be tolerated, and what could not take place in an institution operating under Catholic auspices. For these reasons Catholic entities tried to develop new forms

${ }^{20}$ Euthanasia is an action or omission that of itself or by intention causes death in order to alleviate suffering. Catholic health care institutions may never condone or participate in euthanasia or assisted suicide in any way. Dying patients who request euthanasia should receive loving care, psychological and spiritual support, and appropriate remedies for pain and other symptoms so that they can live with dignity until the time of natural death. The United States Conference of Catholic Bishops, Ethical and Religious Directives for Catholic Health Care Services, no. 60 .

${ }^{21}$ While there are many acts of varying moral gravity that can be identified as intrinsically evil, in the context of contemporary health care the most pressing concerns are currently abortion, euthanasia, assisted suicide, and direct sterilization. See Pope John Paul II, Ad Limina Address to the bishops of Texas, Oklahoma, and Arkansas (Region X), "Origins" 28 (1998) p. 283. See also Reply of the Sacred Congregation for the Doctrine of the Faith on Sterilization in Catholic Hospitals (Quaecumque Sterilizatio), March 13, 1975, "Origins" 6 (1976-1977) pp. 33-35. It would be important to keep in mind the recent response to a question on the liceity of a hysterectomy in certain cases of Sacred Congregation for the Doctrine of the Faith dated December 10, 2018, where it is recognized that hysterectomy can be licit in certain limited situations; see “Origins" 48 (2018-2019), pp. 523-524. 
of sponsorship that would be acceptable. ${ }^{22}$ As an example, rather than having public institutions that were sponsored by a Catholic system follow the Ethical and Religious Directives, a Statement of Common Values was developed which addressed a number of the proscribed procedures.

\section{Public Juridic Person}

As religious congregations continue to diminish in size, it becomes more challenging to fulfill the responsibilities of sponsorship in the ways to which everyone has become accustomed. And so, there has been an evolution of new structures to ensure the appropriate sponsorship of institutions. To understand these new structures, it is important to have a basic understanding of the concept of juridic person, ${ }^{23}$ which can easily be misunderstood. "Juridic person is to canon law what a corporation is to civil law". ${ }^{24}$ It is one of the entities giving canonical effects to an incorporated apostolate. It enables people to come together to perform works or a mission that they would otherwise be unable to accomplish independently. ${ }^{25}$ If a religious congregation and a diocese strive to enter into a partnership to operate jointly certain institutions, such as nursing homes, the usual route is to establish a juridic person for the apostolate for the purpose of being effective in the canonical legal order. ${ }^{26}$ To this end, a decree of a competent ecclesiastical authority is required. In the case of a ministry sponsored by a pontifical religious institute, the petition for distinct juridic status should be directed at this point in time to the Congregation for Institutes of Consecrated Life and Societies of Apostolic Life. In the situation of a bishop

${ }^{22}$ F. G. Morrisey, Our Sponsors Yesterday, Today and Tomorrow, "Health Progress" 94 (2013) 4, p. 59.

${ }^{23}$ For an extensive consideration of this aspect, see Catholic Health Association of the United States, A Guide to Understanding Public Juridic Persons, St. Louis 2012, Catholic Health Association of the United States, p. 97, especially pp. 87-97 for examples of approved statutes of a number of public juridic persons.

${ }^{24}$ Association of Catholic Colleges and Universities, Catholic Colleges and Universities and Their Founding Congregations: Navigating the Waters of Sponsorship, Washington 2018, Association of Catholic Colleges and Universities, p. 6.

${ }^{25}$ M.D. McGowan, Governance/Sponsorship Models of Canadian Catholic Health Care Organizations, Ottawa 1998, Catholic Health Association of Canada, p. 11.

${ }^{26}$ See F.G. Morrisey, Toward Juridic Personality, "Health Progress" 82 (2001) 4, p. 29. 
seeking to establish a diocesan institution as a public juridic person of pontifical right, that petition is usually addressed to the Congregation for the Clergy. ${ }^{27}$ However, if we are simply dealing with one institution situated within a given diocese, it would not be necessary to have pontifical recognition; diocesan status would be sufficient. This means that a public juridic person of pontifical right is constituted by the Apostolic See and is accountable to it. ${ }^{28}$ On the other hand, a public juridic person of diocesan right is constituted by the diocesan bishop and accountable to him. ${ }^{29}$ In order to obtain public juridic personality, the same respective authorities have to approve the statutes (can. 117).

We have to keep in mind that not every health care organization, educational institution, or social work activity has acquired separate juridic personality, just as not every apostolic work has been separately incorporated civilly. Because of the financial consequences, many religious institutes and dioceses are trying to determine which of their works and institutions have received canonical juridic personality. Obtaining juridic personality is highly recommended for a Church entity to carry out its various ministries, if the work is extensive enough to merit separate recognition. It assures canonical control by the juridic person for founding and/or sustaining an apostolic activity. ${ }^{30}$ This juridic personality is distinct from that of the sponsoring diocese or religious institute; as a consequence this helps in determining which temporal goods belong to the works and which belong to the sponsor. Although the structure of a particular juridic person might vary in the light of the charism and the characteristics of its min-

27 P.M. Dugan, The Sponsorship Relationship: Incorporation and Dissolution Civil and Canon Law Perspectives, in R. Smith, W. Brown, N. Reynolds (eds.), Sponsorship in the United States Context. Theory and Praxis, Alexandria 2006, Canon Law Society of America, p. 80.

${ }^{28}$ For instance, the Catholic Health Ministry in 2000 was established by the Congregation for Institutes of Consecrated Life and Societies of Apostolic Life. See M. Kelly, M. Mollison, Journey into Sponsorships' Future, "Health Progress" 86 (2005) 2, p. 50.

${ }^{29}$ Canada, unlike the United States, sometimes submits requests to the Holy See for juridic personality jointly by the sponsoring religious congregations and the bishops of the territories involved. For instance, Catholic Health Sponsors of Ontario, a public juridic person, was established in a way that allows the Catholic Health Association of Ontario (which is jointly sponsored by the bishops and the owners of health care institutions) to assume the seat of any congregation wishing to withdraw from sponsorship of the juridic person. Catholic Health Sponsors of New Brunswick is a joint effort between bishops and religious institutes. Similar arrangements are found with Catholic Health Sponsors of Manitoba where the bishops involved are members of the board of the juridic person.

${ }^{30}$ J. Hite, A Primer on Public and Private Juridic Persons: Applications to the Catholic Health Care Ministry, St. Louis 2000: Catholic Health Association of the United States, p. 37. 
istry, all juridic persons must have in their members certain core competencies to fulfill the canonical responsibility of building up the faith community. ${ }^{31}$

It is worth adding that the form of juridic person in which the laity join with religious and/or clergy to carry out the role and responsibilities of sponsorship is now more commonly called a "ministerial juridic person". Ministerial public juridic person is a response to the needs of the Church today. It can be applied in regard to sponsored ministry in higher education even though it was originally used in sponsored health-care ministry. ${ }^{32}$ Currently this is a reality which we should nurture and co-create. ${ }^{33}$

\section{Co-sponsorship}

In recent years a number of congregations came together to sponsor their systems jointly. ${ }^{34}$ Co-sponsorship is the opposite of a single sponsor system. It means that two or more religious congregations, dioceses, or juridic persons, undertake to support a ministry in a joint vision of its activity. Sometimes it may be more difficult in practice, particularly when the two congregations are the only ones in the area. Their differing traditions may prevent them from cooperating fully. ${ }^{35}$ It does, however, require them to have a better understanding of co-operation between congregations who wish to carry out a ministry jointly. When this joint approach was first initiated, there was a tendency, on the part of some institutes, to exercise their reserved powers over those organizations for which they had formerly been the sole sponsors. However, this became ex-

${ }^{31}$ Catholic Health Association of the United States, Core Competencies of Sponsor, Missouri 2017, St. Louis, p. 1.

${ }^{32}$ Association of Catholic Colleges and Universities, Catholic Colleges and Universities and Their Founding Congregations: Navigating the Waters of Sponsorship, Washington 2018, Association of Catholic Colleges and Universities, p. 7; F.G. Morrisey, P. Martin, Temporal Goods at the Service of the Mission of Ministerial Juridic Persons, St. Louis 2017, Catholic Health Association of the United States, p. 112.

33 A.R. Tersigni, An MPJP Contemplates Charism, Calling and the Future, "Health Progress" 98 (2017) 3, p. 27.

${ }^{34}$ One of the most recent examples of this is Bon Secours Mercy Ministries, a joint undertaking of the Sisters of Bon Secours, the Sisters of Mercy of the Americas, and the Sisters of the Humility of Mary, approved by the Holy See, December 14, 2018.

35 F.G. Morrisey, Catholic Identity in a Challenging Environment, "Health Progress" 80 (1999) 6, p. 41. 
tremely complicated as, over time, funds and operations became increasingly mingled. ${ }^{36}$ As a result, co-sponsors soon began to delegate most of these powers, on a permanent basis, to a new board representing all the congregations involved in the joint venture. The only reserved powers not delegated were those relating to property ownership or similar matters reserved to the original sponsors and the appointment of representatives of the congregation to various boards. A study published in 2014 noted that some co-sponsorship leaders pointed out that the co-sponsorship system, although it may be effective for some of them, is not for everyone. ${ }^{37}$

One of the advantages of co-sponsorship is that it makes the mission and Catholic character of the sponsored work more important than the particular charism of the original sponsoring congregation. And indeed, discerning the component elements of a particular charism is sometimes difficult. In practice, most of the charisms of religious institutes have much in common - starting with the following of Christ.

Clearly, changes in co-sponsorship affect all involved in sponsored works, but the original sponsors themselves are often most strongly affected. For these congregations, a new approach to sponsorship can, at first, lead to a sense of loss or distancing. Such changes require new ways of thinking. For example, sponsors of co-sponsored systems must begin to consider the whole system, not just an individual institution. It is important to know that where there is a will, there is a way. ${ }^{38}$

\section{Lay persons involved in sponsorship}

Lay people became more engaged in the life of the Church in response to the call of the Second Vatican Council to live out their baptismal commitment. As noted earlier, this coincided with a decline in religious vocations and the aging of members of religious institutes ${ }^{39}$ who sponsored and staffed charitable institutions.

36 O. Bordelon, The Co-sponsorship Model, "Health Progress" 82 (2001) 4, p. 46.

37 C.S. Clark, Sponsorship The JRK Study, "Health Progress" 86 (2005) 1, p. 46.

38 Ibidem.

39 Catholic Health Association of the United States' report prepared for the board of trustees in 1988, some thirty years ago, released dramatic statistics. Approximately 10 percent of Catholic health care institutions were sponsored by religious institutes (congregations) with 100 or fewer members, and another 12 percent were sponsored by religious institutes with 200 or fewer 
For these reasons, lay persons assumed greater responsibility for the mission, vision and Catholic identity of the incorporated apostolate. ${ }^{40}$ With time, lay persons became involved not only in partnership but also in the decision-making processes, ${ }^{41}$ collaborating in this respect with the founding religious congregations. ${ }^{42}$ Some religious institutes turned their sponsorship responsibilities over to lay groups, without first reaching a clear understanding of the responsibilities being transferred and without a strong mutual agreement. ${ }^{43}$ This in turn, raised the question of how many lay people are fully prepared to serve as leaders of Catholic healthcare organizations, and in particular whether they will be able to maintain Catholic identity and the Church's teachings, ${ }^{44}$ and will they carry on the charism and core values of their founders. ${ }^{45}$

Today we can note that ministry leaders are often chosen for their business acumen rather than their faith commitment or fidelity to the Church's teaching. It is essential that the lay people who are assuming these responsibilities be adequately prepared for work in sponsored organizations. They should be accountable for maintaining Catholic identity and fidelity to the Gospel teaching of the Church's ministries in service to the common good and the charism of the religious sponsor. ${ }^{46}$ Ministry leaders need to understand their work as some-

members. In both cases, the median age of the sisters was 65 . Further, the rapidly changing and increasingly complex business environment demanded new management models. P. Schaeffer, The Changing Face of Leadership, "Health Progress" 95 (2014) 5, p. 42.

${ }^{40}$ Catholic Health Association of the United States, Core Competencies of Sponsor, Missouri 2017, St. Louis, p. 1.

${ }^{41}$ We have to keep in mind that the Second Vatican Council affirmed the responsibility of the laity for the Church's ministries. pp. $42-51$.

${ }^{42}$ Cf. P. Schaeffer, The Changing Face of Leadership, "Health Progress" 95 (2014) 5,

${ }^{43}$ D.C. Conlin, Sponsorship at the Crossroads, "Health Progress" 82 (2001) 4, p. 21.

${ }^{44}$ Catholic health care ministry is rooted in a commitment to promote and defend human dignity; this is the foundation of its concern to respect the sacredness of every human life from the moment of conception until death. Pope John XXIII, Encyclical Letter Peace on Earth, Pacem in Terris, Washington DC 1963: United States Conference of Catholic Bishops, no. 11; Catechism of the Catholic Church, 2nd ed., Washington DC 2000, Libreria Editrice Vaticana, no. 2211.

45 Association of Catholic Colleges and Universities, Catholic Colleges and Universities and Their Founding Congregations: Navigating the Waters of Sponsorship, Washington 2018, p. 1.

${ }^{46}$ In this regard, see Congregation for Institutes of Consecrated Life and Societies of Apostolic Life, Economy at the Service of the Charism and Mission, Vatican City 2018, 136p., especially pp. $83-130$. 
thing greater and more encompassing than itself. Therefore, the need for sound sponsorship leadership training was recognized so that people would be suitably prepared to perform their tasks. It is not enough to recruit skilled persons off the street, give to them Ethical and Religious Directives to read and announce that they are sufficiently formed to assume leadership responsibilities. Leaders need a formation program. In this context, one may ask whether they are aware of acting on behalf of the Church? Acting on the Church's behalf implies a "church mindset", where one sees health care as an integral, interrelated part of the organic whole that is the Church. Ultimately they should be aware of serving the Church, not only a particular charitable organization. ${ }^{47}$ They should, for instance, also be made aware of the developments in moral and ethical teachings in order to exercise responsible stewardship over the temporal goods entrusted to their care. They should be particularly careful when considering proposed new mergers, amalgamations, joint ventures, closing down and so forth ${ }^{48}$ The various Catholic health associations and MJPs have been focusing on this dimension for the past few years, and the results are most encouraging.

In the future, given the rapid changes in society and in technology, especially in the area of healthcare, the Church will need more persons who know its official positions relating to medical ethics and who can apply these positions prudently. ${ }^{49}$ We can note that in some parts of the United State for instance, Catholic providers are expected to offer arrangements for a full range of procedures, including some forbidden by the Church (e.g., contraceptives, sterilization), in order to receive financial support from the government. This becomes particularly delicate in those circumstances where a Catholic healthcare institution is the only one situated within a given geographic area. ${ }^{50}$ For this very reason, the selection of appropriate board members is crucial in order to ensure the continuity of Catholic identity. The Church needs to initiate more formation programs in order to support board members' role as well as an ongoing explora-

${ }^{47}$ C. Lowney, Ministry Leadership’s Next Great Leap, "Health Progress" 98 (2017) 3, p. 22.

${ }^{48}$ See more M.K. Grant, M.M. Kopish, Sponsor Leadership Formation, "Health Progress" 82 (2001) 4, p. 26; P. Smith, Sponsors as Supporters, "Health Progress" 90 (2009) 6, p. 17.

49 The United States Conference of Catholic Bishops recommends that in every Catholic health care institution an ethics committee or some alternate form of ethical consultation should be available to assist by advising on particular ethical situations. Ethical and Religious Directives for Catholic Health Care Services, no. 37.

${ }^{50}$ F.G. Morrisey, Restructuring systems: A call for dialogue. Are We Painting Ourselves into a Corner?, "Health Progress" 94 (2013) 1, pp. 66-67. 
tion of sponsorship responsibilities. Moreover, Catholic health care services must adopt the policy of Ethical and Religious Directives for Catholic Health Care Services and ensure adherence within the institution as a condition for employment as well as assurance of appropriate instructions for medical, nursing and other staff. In relation to Catholic educational institutions, the applicable norms of $E x$ Corde Ecclesiae provide the framework for appropriate decision-making. ${ }^{51}$ The field of Catholic social services is one that is fraught with many tensions today, again at times depending on various forms of pressure exerted by funding entities.

Co-operation with lay persons is a relatively new approach in understanding Catholic sponsorship. It takes time to build trust among potential partners and to learn one another's perspectives on co-operation. ${ }^{52}$

\section{Dealing with For-Profit Organizations}

The decline in religious vocations, lack of access by an increasing proportion of the population and spiraling costs are factors which led to the search for a new approach to sponsorship. ${ }^{53}$ Under such economic conditions, non-profit organizations are often unable to provide the same level of community benefits. In some instances, this resulted in the take over and operation of Catholic institutions on a for-profit basis ${ }^{54}$ whilst simultaneously maintaining that these institutions remained Catholic, through some type of contractual agreement.

${ }^{51}$ For an extensive consideration of this aspect, see John Paul II, Apostolic Constitution, Ex Corde Ecclesiae, 15 August 1990, "Acta Apostolicce Sedis" 82 (1990) pp. 1475-1509; English translation, Apostolic Constitution of the Supreme Pontiff John Paul II on Catholic Universities, Vatican City 1990, Libreria Editrice Vaticana; J.H. Provost, The Canonical Aspects of Catholic Identity in the Light of »Ex Corde Eccleasiae", "Studia Canonica" 25 (1991) pp. 155-191.

52 F.G. Morrisey, Catholic Identity in a Challenging Environment, "Health Progress" 80 (1999) 6, p. 41.

53 W. J. Cox, Health Care Reform: The Catholic Perspective, “The Catholic Lawyer" 35 (1993) 3, pp. 217-224; The Catholic Health Association developed policy recommendations for healthcare reform to help respond to the American healthcare crisis. As circumstances changed, so too did the policy recommendations. For an idea of the issues facing leaders some 30 years ago, see J.A. Calfiano, Rationing Health Care: America's Self-Inflicted Wound, "Stanford Law \& Policy Review" (1991) 2, pp. 36-41. It is interesting to note how many of these points are still relevant today.

${ }^{54}$ For instance, Saint Louis University Hospital in 1997 was sold to a for-profit corporation. In June 2015, the university announced that it would reacquire the hospital and transfer it to the non-profit Catholic hospital system SSM Health Care. 
This can be very risky and can lead to a change in the nature of the work from that of an apostolate to that of a business. Partnership with non-faith-based health care providers may even threaten the continued existence of Catholic institutions and services, particularly when partnerships are driven by financial considerations alone. It is therefore essential that any partnerships that affect the mission, or the religious and ethical identity of Catholic health care institutional services must respect Church teaching and discipline. The United States Conference of Catholic Bishops recommends that "Decisions that may lead to serious consequences for the identity or reputation of Catholic health care services, or entail the high risk of scandal, should be made in consultation with the diocesan bishop or his health care liaison.". ${ }^{55}$

We can currently find many opportunities for dealing with for-profit organizations. It is important, however, to keep in mind that this approach could, at times, be contradictory in terms, because, in general, Catholic institutions are an integral part of the larger framework of non-profit organizations ${ }^{56}$ and the endeavor to take over the Catholic health care institution on a for-profit basis should not simply be the subject of mutual agreements. It should include the relevant requirements of canon law to be observed with regard to operating the Catholic health care institution.

\section{Possible Future Directions}

When it comes to Catholic colleges and universities, sponsorship will continue to play a significant role in the lives of Catholic colleges and universities. Its structural components will necessarily evolve as religious congregations and institutions remain committed to living out the sponsor's values and charism in their college or university. This evolution will involve experiments with different structures and processes to achieve an appropriate balance between the sponsored institution and the sponsoring entity. Ongoing deliberations with the Holy See will play a critical role in these developments. We have to keep in mind that with fewer religious on Catholic campuses, there can be a tendency

55 The United States Conference of Catholic Bishops, Ethical and Religious Directives for Catholic Health Care Services, no. 67.

${ }^{56}$ C.E. Cochran, K.R. White, Does Catholic Sponsorship Matters?, "Health Progress" 83 (2002) 1, p. 14. 
to reclaim authority and control, through greater prescription of behavior, in an attempt to ensure that essential congregational values are maintained. Reserved powers will be verified to ascertain if the sponsoring congregation should claim primary authority in additional governance areas. ${ }^{57}$

On the other hand, Catholic health care organizations may continue their service through outpatient service or forms of compassionate care. This practice may be used especially in the area of senior care, palliative care, rehabilitation and in home nursing. The growing need for long term care, for the supportive care of the dying, and for mental-illness and addiction treatment will mean that Catholic health care could change from acute care hospitals to smaller, community-based settings. We have to note, that the setting for compassionate care is not a hospital, but rather the patient's home or an ambulatory clinic, hospice, or nursing home. This in turn means that efforts to foster and maintain the Catholic identity should take place at various levels. ${ }^{58}$ It also offers a different perspective on Catholic health care ministry. It is addressed to poor, low-income and vulnerable people.

These directions bring us back to a fundamental principle. Sponsorship organizations were the answer to the needs of people and Church communities. The establishment and maintenance of so many healthcare, education, and social services were wrought through hard work, choices and priorities of religious women, men and lay people. Looking ahead we must trust that next generation of people will also pursue sponsorship services on a cooperative basis with religious and lay people.

\section{Conclusion}

Catholic healthcare organizations and services are striving to find ways whereby they can continue their ministry without compromising their identity. Each vision of understanding of Catholic health care had its unique influence on the way in which Catholic health care facilities were seen. In all of these configurations of public juridic persons, the diocesan bishop is to continue to exercise

57 Association of Catholic Colleges and Universities, Catholic Colleges and Universities and Their Founding Congregations: Navigating the Waters of Sponsorship, Washington 2018, p. 10.

${ }^{58}$ K. Connors, Catholic Identity in New Sponsorship Models, "Health Progress" 98 (2017) 3, p. 33. 
responsibility for the works of the Church within his diocese (can. 394, \$1). As the composition of persons responsible for apostolic works in the Church changes, appropriate formation with a focus on limits of executive authority is also becoming increasingly important. To this day, the authority of the Church to direct and control apostolates granted public juridic personality must be reinforced, lest civil corporate status disenfranchise the Church's primary position of responsibility for the ways its mission is carried out in the Church.

With regard to the evolution of sponsorship, it is evident that the process is still underway. The delivery of healthcare is continually being transformed and reshaped. Educational institutions are not far behind, and the social service providers are continually faced with difficult moral choices. Catholic health care organizations and services finding themselves within this evolving context, are constantly seeking how best to secure their future in the light of current legislation and the evolution of sponsorship practices. Since the Catholic Church is the largest provider of healthcare services in the world, it is essential that various situations are taken into account. One size cannot possibly fit all institutions and establishments operating under the name of the Church.

The analysis of the present situation shows that we have probably not yet discovered the most suitable sponsorship model by which to resolve all difficulties relating to the mission, vision and identity of the apostolic activity. Indeed, we have to conduct and strengthen dialogue with potential partners, avoiding extreme positions. Despite the complex nature of health care delivery and ways of financing, ensuring adequate care to all is clearly an obligation of justice. In addition to determining sponsorship responsibilities, we can keep in mind that Catholic health care also has an important role to play in influencing practice patterns and models of care delivery.

The Church's mission is to continue the mission of Jesus in our world. Finally, Christian life as a whole and the canonical norms are intended to support the faithful on the journey to the intimate union with God for eternity, which is summed up in the final canon of the Code of Canon law: "the salvation of souls, which must always be the supreme law in the Church, is to be kept before one's eyes". 


\section{Bibliography}

\section{Sources of law}

Catechism of the Catholic Church, $2^{\text {nd }}$ ed., Washington DC 2000: Libreria Editrice Vaticana.

Codex Iuris Canonici auctoritate Ioannis Pauli PP. II promulgatus 25 January 1983, AAS 75 (1983), part II, pp. 1-317.

Congregation for Doctrine of the Faith, Response to a question on the liceity of a hysterectomy in certain cases (10 December 2018), "Origins" 48 (2018-2019), pp. 523-524.

Congregation for Institutes of Consecrated Life and Societies of Apostolic Life, Economy at the Service of the Charism and Mission, Vatican City 2018.

John Paul II, Apostolic Constitution, Ex Corde Ecclesiae, 15 August 1990, “Acta Apostolicce Sedis” 82 (1990) pp. 1475-1509; English translation, Apostolic Constitution of the Supreme Pontiff John Paul II on Catholic Universities, Vatican City 1990: Libreria editrice Vaticana.

John XXIII, Encyclical Letter Peace on Earth, Pacem in Terris,Washington DC 1963: United States Conference of Catholic Bishops.

\section{Literature}

Association of Catholic Colleges and Universities, Catholic Colleges and Universities and Their Founding Congregations: Navigating the Waters of Sponsorship, Washington 2018: Association of Catholic Colleges and Universities.

Association of Catholic Colleges and Universities, Points of Distinction: The Catholic College and University President, Washington 2018: Association of Catholic Colleges and Universities.

Black H.C., Black's Law Dictionary: Definitions of the Terms and Phrases of American and English Jurisprudence Ancient and Modern, St. Paul 1990: West Publishing Co.

Bordelon O., The Co-sponsorship Model, "Health Progress" 82 (2001) 4, pp. 46-47.

Calfiano J.A., Rationing Health Care: America's Self-Inflicted Wound, "Stanford Law \& Policy Review" (1991) 2, pp. 36-41.

Catholic Health Association of the United States, A Guide to Understanding Public Juridic Persons, St. Louis 2012: Catholic Health Association of the United States.

Catholic Health Association of the United States, Core Competencies of Sponsor, Missouri 2017: St. Louis.

Clark C.S., Sponsorship The JRK Study, “Health Progress” 86 (2005) 1, pp. 45-47.

Cochran C.E., White K.R., Does Catholic Sponsorship Matters?, "Health Progress" 83 (2002) 1, pp. 14-16.

Conlin D.C. Sponsorship at the Crossroads, "Health Progress" 82 (2001) 4, pp. 20-23. 
Connors K., Catholic Identity in New Sponsorship Models, "Health Progress" 98 (2017) 3, pp. 31-33.

Cox W. J., Health Care Reform: The Catholic Perspective, “The Catholic Lawyer” 35 (1993) 3, pp. 217-224.

Dugan P.M., The Sponsorship Relationship: Incorporation and Dissolution Civil and Canon Law Perspectives, in R. Smith, W. Brown, N. Reynolds (eds.), Sponsorship in the United States Context. Theory and Praxis, Alexandria 2006: Canon Law Society of America, pp. 73-83.

Grant M.K., Kopish M. M., Sponsor Leadership Formation, “Health Progress” 82 (2001) 4, pp. 24-26.

Hite J., A Primer on Public and Private Juridic Persons: Applications to the Catholic Health Care Ministry, St. Louis 2000: Catholic Health Association of the United States.

Kealy R., Canonical Aspects of Catholic Identity in the Institutional Setting, "Canon Law Society of America Proceedings" 61 (1999) pp. 195-209.

Keane P.S., Health Care Reform: A Catholic View, New York 1993: Paulist Press.

Kelly M., Mollison M., Journey into Sponsorships' Future, “Health Progress” 86 (2005) 2, pp. 50-53.

Lowney C., Ministry Leadership's Next Great Leap, “Health Progress” 98 (2017) 3, pp. 17-23.

Maida A.J., Cafardi N.P., Church Property, Church Finances, and Church-related Corporations: A Canon Law Handbook, St. Louis 1984: Catholic Health Association of the United States.

McGowan M.D., Governance/Sponsorship Models of Canadian Catholic Health Care Organizations, Ottawa 1998: Catholic Health Association of Canada.

Morrisey F.G., Catholic Identity in a Challenging Environment, "Health Progress" 80 (1999) 6, pp. 38-42.

Morrisey F.G., Martin P., Temporal Goods at the Service of the Mission of Ministerial Juridic Persons, St. Louis 2017: Catholic Health Association of the United States.

Morrisey F.G., Our Sponsors Yesterday, Today and Tomorrow, "Health Progress" 94 (2013) 4, pp. 57-66.

Morrisey F.G., Restructuring systems: A call for dialogue. Are We Painting Ourselves into a Corner?, "Health Progress" 94 (2013) 1, pp. 66-67.

Morrisey F.G., Toward Juridic Personality, “Health Progress” 82 (2001) 4, pp. 27-31.

Murphy J.K., The governance of Church institutions and protection of Catholic identity with particular reference to Ontario, Canada, Roma 1995: Pontificia Università Lateranense.

Pope John Paul II, Ad Limina Address to the bishops of Texas, Oklahoma, and Arkansas (Region X), “Origins” 28 (1998) p. 283.

Provost J.H., The Canonical Aspects of Catholic Identity in the Light of "Ex Corde Eccleasiae", "Studia Canonica" 25 (1991) pp. 155-191.

Sacred Congregation for the Doctrine of the Faith, Reply of the Sacred Congregation 